\title{
Environmental pollution and deaths due to stroke in a city with low levels of air pollution: ecological time series study
}

Poluição ambiental e óbitos devido a acidente vásculo-encefálico em uma cidade com baixos níveis de poluentes: estudo ecológico de séries temporais

\author{
Camila Trolez Amancio', Luiz Fernando Nascimento" \\ Department of Medicine, Universidade de Taubaté (Unitau), Taubaté, São Paulo, Brazil
}

'Medical Student. Department of Medicine, Universidade de Taubaté (Unitau), Taubaté, São Paulo, Brazil.

IPhD. Assistant Professor, Department of Medicine, Universidade de Taubaté (Unitau), Taubaté, São Paulo, Brazil.

\section{KEY WORDS:}

Stroke.

Air pollutants.

Particulate matter.

Mortality.

Sulfur dioxide.

\section{PALAVRAS-CHAVE:}

Acidente vascular cerebral.

Poluentes do ar.

Material particulado.

Mortalidade.

Dióxido de enxofre.

\begin{abstract}
CONTEXT AND OBJECTIVE: Little has been discussed about the increased risk of stroke after exposure to air pollutants, particularly in Brazil. The mechanisms through which air pollution can influence occurrences of vascular events such as stroke are still poorly understood. The aim of this study was to estimate the association between exposure to some air pollutants and risk of death due to stroke.

DESIGN AND SETTING: Ecological time series study with data from São José dos Campos, Brazil.

METHODS: Data on deaths due to stroke among individuals of all ages living in São José dos Campos and on particulate matter, sulfur dioxide and ozone were used. Statistical analysis was performed using a generalized additive model of Poisson regression with the Statistica software, in unipollutant and multipollutant models. The percentage increase in the risk of increased interquartile difference was calculated. RESULTS: There were 1,032 deaths due to stroke, ranging from 0 to 5 per day. The statistical significance of the exposure to particulate matter was ascertained in the unipollutant model and the importance of particulate matter and sulfur dioxide, in the multipollutant model. The increases in risk were $10 \%$ and $7 \%$, for particulate matter and sulfur dioxide, respectively.

CONCLUSION: It was possible to identify exposure to air pollutants as a risk factor for death due to stroke, even in a city with low levels of air pollution.
\end{abstract}

\section{RESUMO}

CONTEXTO E OBJETIVO: Pouco se tem discutido sobre o aumento do risco de acidente vascular cerebral após exposição a poluentes do ar, principalmente no Brasil. Os mecanismos pelos quais a poluição pode influenciar a ocorrência de eventos vasculares, tais como acidente vascular cerebral, ainda são pouco compreendidos. O objetivo deste estudo foi estimar a associação entre exposição a alguns poluentes do ar e risco de morte por acidente vascular cerebral.

TIPO DE ESTUDO E LOCAL: Estudo ecológico de séries temporais com dados de São José dos Campos, Brasil. MÉTODOS: Dados sobre mortes por acidente vascular cerebral em indivíduos de todas as idades que vivem em São José dos Campos e sobre material particulado, dióxido de enxofre e ozônio foram utilizados. A análise estatística utilizou modelo aditivo generalizado de regressão de Poisson com o software Statistica, em modelos "unipollutant" e "multipollutant". Foi calculado o percentual de aumento no risco para o aumento da diferença interquartil.

RESULTADOS: Houve 1.032 mortes por acidente vascular cerebral, que variou de 0 a 5 por dia. A significância estatística da exposição ao material particulado em modelo "unipoluente" e a importância do material particulado e dióxido de enxofre no modelo "multipoluente" foram verificadas. O aumento do risco foi de 10\% e 7\%, respectivamente para material particulado e dióxido de enxofre.

CONCLUSÃO: Foi possível identificar exposição a poluentes do ar como um fator de risco para morte por acidente vascular cerebral, mesmo em uma cidade com baixos níveis de poluição do ar. 


\section{INTRODUCTION}

The deleterious effects of exposure to environmental pollution have been studied recently in Brazil, focusing mainly on diseases of the respiratory and circulatory systems and the increased risk of morbidity and mortality was confirmed. ${ }^{1-4}$ However, little has been discussed about the increased risk of stroke, particularly in Brazil. An association between stroke and exposure to air pollutants has been shown, in Europe, Asia and Brazil, mainly covering hospitalization due to this cause..$^{5-8}$ Recent studies have also shown that the risk of stroke is also greater in regions with low levels of pollutants. ${ }^{6,9}$

Stroke deserves special attention because it is the leading cause of disability worldwide, compromising the quality of life of those who fall ill as a consequence of it. Thus, stroke, characterized by rapid loss of neurological function due to ischemia or hemorrhaging of brain vessels, is a serious public health problem. ${ }^{10}$ In 2009, in Brazil, about US\$ 200 million were invested in clinical treatments for affected patients. ${ }^{11}$

The pollutants studied and most commonly associated with deleterious effects on human health are particulate matter $\left(\mathrm{PM}_{10}\right)$, sulfur dioxide $\left(\mathrm{SO}_{2}\right)$ and ozone $\left(\mathrm{O}_{3}\right) \cdot \mathrm{PM}_{10}$ is a mixture of solid and liquid particles suspended in air; $\mathrm{SO}_{2}$ is generated from combustion of fossil elements and $\mathrm{O}_{3}$ is formed by reaction between ultraviolet radiation, nitrogen oxides and hydrocarbons emitted by vehicles. ${ }^{12}$

However, the mechanisms through which air pollution may influence occurrences of vascular events such as stroke remain poorly understood. It has been shown in relation to cardiovascular mortality that fine particulate matter acts through mechanisms that include systemic inflammation, accelerated atherosclerosis and altered cardiac autonomic function. ${ }^{13}$

\section{OBJECTIVE}

Due to the uncertainties that still exist on this subject, the aim of the present study was to estimate the association between exposure to major air pollutants and risk of death due to stroke in a medium-sized city in Brazil, with low levels of air pollution.

\section{METHODS}

This was an ecological time series study covering a five-year period (January 1, 2005, to December 31, 2009), using information on deaths due to stroke among individuals of all ages living in the city of São José dos Campos. Diagnoses were coded in accordance with the $10^{\text {th }}$ International Classification of Diseases (ICD-10), taking into account the definitions I-60 to I-69. This information was obtained from the Mortality Information System (SIM).

São José dos Campos is located between São Paulo and Rio de Janeiro, at latitude $23^{\circ} 11^{\prime}$ south and longitude $45^{\circ} 53^{\prime}$ west,
600 meters above sea level. It is an important industrial and commercial center in this region and has approximately 600,000 inhabitants. It has about 1100 industrial establishments with emphasis on automobile manufacturing, aerospace and pharmaceutical industries, and an oil refinery (information available on www.ibge.gov.br). The city is crossed by the Dutra highway, which is the most important highway in Brazil, with heavy traffic involving about 130,000 vehicles per day, including cars, trucks and buses.

The pollutants included in the analysis were particulate matter with an aerodynamic diameter $<10 \mu \mathrm{m}\left(\mathrm{PM}_{10}\right)$, sulfur dioxide $\left(\mathrm{SO}_{2}\right)$ and ozone $\left(\mathrm{O}_{3}\right)$. The data were obtained from the São Paulo State Environmental Agency (CETESB), which has a measuring station in downtown São José dos Campos. Meteorological data such as relative humidity, average temperature and atmospheric pressure were obtained from the Foundation for Science, Technology and Space Applications (FUNCATE). The pollutant concentration values used were taken from a CETESB report. ${ }^{14}$

We built distributed lag models covering the times of 0 to 5 days after exposure, because the acute effects of exposure to air pollutants can manifest several days after this exposure.

The analysis was adjusted for average temperature, humidity and atmospheric pressure. The pollutant data were analyzed in continuous unipollutant and multipollutant models, such that all three pollutants were firstly studied separately, and subsequently together.

The statistical analysis used was the generalized additive model (GAM) of Poisson regression, with the Statistica software. The analysis yielded relative risks (RR) and 95\% confidence intervals (CI) for each lag structure constructed.

In the multipollutant model, we calculated the percentage increase in risk caused by increases in the interquartile difference (IQD) in pollutant concentration, by means of the formula:

$\mathrm{PI}=\left[\exp \left(\right.\right.$ coeff $\left.\left.\mathrm{VIQPOL}{ }^{\star}\right)-1\right]{ }^{\star} 100$

where PI is the percentage increase in the risk of death due to stroke and VIQPOL is the difference between the third and first quartiles of the pollutant concentration. A significance level of $5 \%$ was used for all the analyses.

\section{RESULTS}

During the study period, there were 1032 recorded deaths due to stroke among individuals of all ages living in São José dos Campos, thus generating a daily mean of $0.56(\mathrm{SD}=0.77)$ and a range from 0 to 5 .

In relation to air pollutants, the mean $\mathrm{PM}_{10}$ was $24 \mathrm{mg} / \mathrm{m}^{3}$ $(\mathrm{SD}=12.4)$, without exceeding the established standard of an acceptable annual mean of $50 \mu \mathrm{g} / \mathrm{m}^{3}$. The annual daily mean for $\mathrm{SO}_{2}$ was $3.5 \mu \mathrm{g} / \mathrm{m}^{3}(\mathrm{SD}=2.6$ ), without exceeding the established value of $80 \mu \mathrm{g} / \mathrm{m}^{3}$. The maximum daily $\mathrm{O}_{3}$ concentration for one 
hour was $209 \mu \mathrm{g} / \mathrm{m}^{3}$, which exceeded the maximum acceptable for this length of time per day, which is $80 \mu \mathrm{g} / \mathrm{m}^{3}$. The interquartile differences obtained were $15 \mu \mathrm{g} / \mathrm{m}^{3}$ for $\mathrm{PM}_{10}, 2 \mu \mathrm{g} / \mathrm{m}^{3}$ for $\mathrm{SO}_{2}$ and $41 \mu \mathrm{g} / \mathrm{m}^{3}$ for $\mathrm{O}_{3}$. These data are summarized in Table 1 .

Figure 1 shows the variation in pollutant levels over the five years of the study. It is interesting to note that there was seasonal variation of the pollutants particulate matter and sulfur dioxide, which increased in level during the colder periods of the year.

Regarding data gaps, there were data on the pollutant levels for particulate matter on 90 days (4.9\%), sulfur dioxide on 332 days (18.1\%) and ozone on 136 days (7.4\%). However, these data gaps did not damage the final outcome from the study.

A statistically significant association between exposure to particulate matter and death due to stroke (RR: 1.005; 95\% CI: 1.000 to 1.011 ) on the same day as the exposure (lag 0 ) was noted in the unipollutant model. No significant association was found for the other pollutants.

Figure 2 shows the relative risks for each lag structure and their respective $95 \%$ confidence intervals for death due to stroke in the multipollutant model. Deaths due to stroke were significantly associated with exposure to particulate matter on the same day as the exposure (RR: 1.007; 95\% CI: 1.000 to 1.014); and with exposure to sulfur dioxide on the fifth day after exposure (lag 5) (RR: 1.033 ; 95\% CI: 1.004 to 1.063 ).

In relation to increases in the interquartile difference for the pollutant in the multipollutant model, we observed that there was a statistically significant increased risk of death of approximately $10 \%$ on the same day as the exposure to $\mathrm{PM}_{10}$ and $7 \%$ on the fifth day after exposure to $\mathrm{SO}_{2}$, as shown in Figure 3.

\section{DISCUSSION}

An increased risk of hospitalization due to stroke was observed in the city of São José dos Campos. This is one of the first cities in Brazil for which estimates for the risk of death from this cause have been made. ${ }^{8}$ This finding deserves attention because little research has been conducted worldwide on the association between exposure to air pollutants and stroke.

The use of lags to estimate the risk of death is widely used in methodologies worldwide, while the number of lags analyzed has varied. ${ }^{6,15}$ We chose to use five days of lag because of the possibility that this might produce a more comprehensive approach, thereby agreeing with the Korean methodology. ${ }^{16}$

The statistical analysis for this approach was the generalized additive model of Poisson regression, which had already been established for this type of analysis, since the variables under assessment are counted variables. However, some studies have addressed this issue by making use of a generalized linear model. ${ }^{4,8}$ It has already been found that both the additive and the linear model show consistent results. ${ }^{17}$
Table 1. Descriptive analysis on the variables under assessment. São José dos Campos, Brazil, 2005-2009

\begin{tabular}{lccccc|} 
& Mean & SD & Minimum & Maximum & IQD \\
\hline Deaths & 0.56 & 0.77 & 0 & 5 & \\
$\mathrm{PM}_{10}\left(\mu \mathrm{g} / \mathrm{m}^{3}\right)$ & 23.96 & 12.41 & 6 & 100 & 15 \\
$\mathrm{SO}_{2}\left(\mu \mathrm{g} / \mathrm{m}^{3}\right)$ & 3.45 & 2.57 & 0.5 & 27 & 2 \\
$\mathrm{O}_{3}\left(\mu \mathrm{g} / \mathrm{m}^{3}\right)$ & 80.62 & 32.24 & 5 & 209 & 41 \\
Humidity $(\%)$ & 83.52 & 7.25 & 54.0 & 100 & \\
Temperature $\left({ }^{\circ} \mathrm{C}\right)$ & 20.7 & 2.45 & 13.7 & 27.9 & \\
Pressure (mbar) & 948.2 & 3.33 & 938 & 960 & \\
\hline
\end{tabular}

$\mathrm{SD}=$ standard deviation; $\mathrm{IQD}=$ interquartile difference.

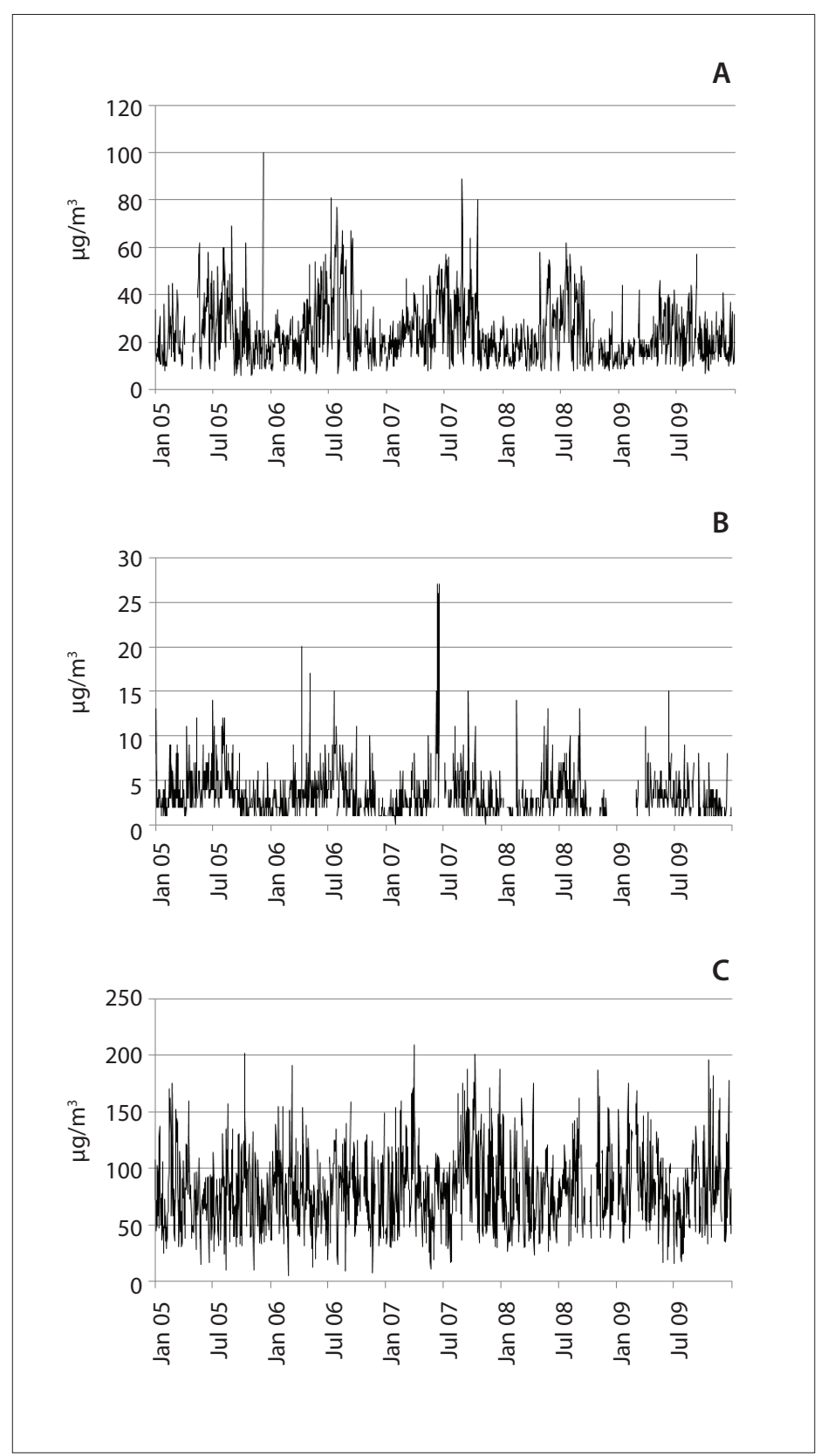

Figure 1. Pollutant levels in $\mu \mathrm{g} / \mathrm{m}^{3}$ : (A) particulate matter; (B) sulfur dioxide; (C) ozone. São José dos Campos, Brazil, 2005-2009. 

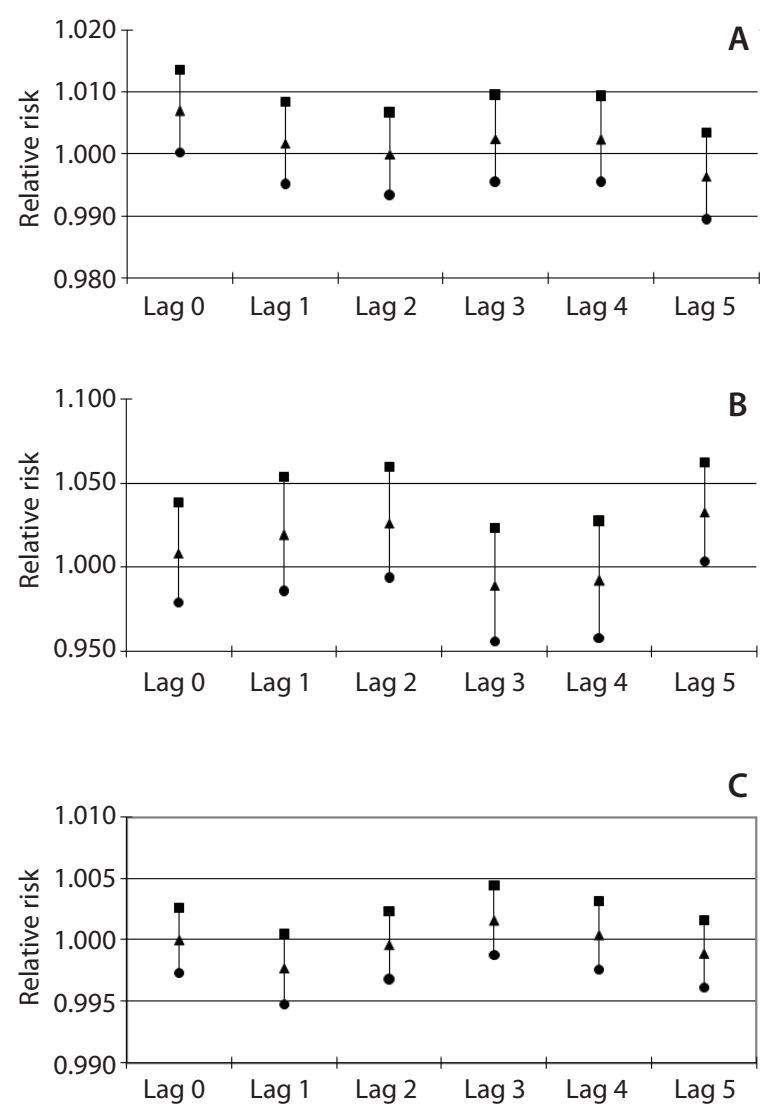

Figure 2. Relative risks and $95 \%$ confidence intervals in relation to multipollutant model; (A) particulate matter; (B) sulfur dioxide; (C) ozone. São José dos Campos, Brazil, 2005-2009.

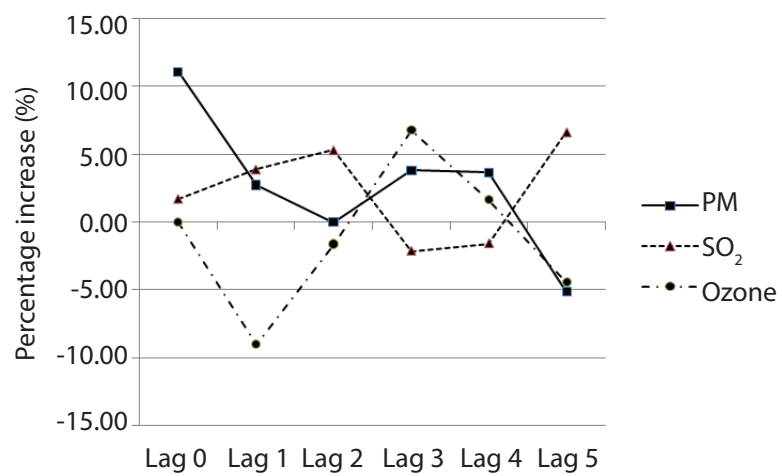

Figure 3. Percentage increase in relative risk, in multipollutant model according to lags. São José dos Campos, Brazil, 2005-2009.

To select cases of death due to stroke obtained from the Mortality Information System (SIM), we used the International Classification of Diseases in its tenth revision (ICD-10), including diagnoses classified as I60 to I69 together for analyses.
The deaths due to stroke were not separated into ischemic or hemorrhagic types, which has been recommended in some studies, ${ }^{7,15}$ because most of the deaths recorded during the period covered by this study were categorized as unspecified stroke.

This study showed that significant exposure to particulate matter was a risk factor for death due to stroke both in the unipollutant and in the multipollutant model. There was a $10 \%$ higher risk of a greater interquartile difference, which was more than what was found by Wellenius et al. (1.03\%) for ischemic stroke. ${ }^{15}$ A positive association between stroke mortality and the level of exposure to fine particulate matter $\left(\mathrm{PM}_{2.5}\right)$ on the same day and preceding day, and also to ultrafine particles on the preceding day, was reported in a study developed in Helsinki, during the summer season. ${ }^{6}$

The activation of microglia in response to air pollution and identification of particulate matter both in brain capillaries and in parenchyma suggest that particulate matter is capable of interacting with cells and crossing the blood-brain barrier. ${ }^{18,19}$ Recent advances have shown that systemic inflammation has a significant impact on brain tissue. It has been accepted that air pollution causes proinflammatory signals originating in peripheral organs such as the lungs, which transfer inflammation to the brain..$^{20}$ As an example, one study showed that in response to tumor necrosis factor alpha (TNF alpha) during inflammation of a peripheral organ, animals appeared to recruit larger quantities of circulating monocytes to the brain. ${ }^{21}$

In the present, sulfur dioxide was significant in the multipollutant model only in relation to the five-day lag, unlike the findings of another study, in which this pollutant was a significant risk factor for exposure on the same day, for inclusion in the unipollutant model (RR: 1029; 95\% CI: 1.000-1.060). ${ }^{8}$ This might be explained by the different focus of that study, since hospital admissions and not deaths were taken into consideration. In Seoul, Korea, there was a $2.9 \%$ higher risk of a greater interquartile difference, two days after exposure in the unipollutant model, with a mean $\mathrm{SO}_{2}$ concentration of $30 \mu \mathrm{g} / \mathrm{m}^{3}$, i.e. well above what was found in the present study. ${ }^{16}$ Although it was expected that the increased risk of mortality would be greater in the area where the pollutant concentration was highest, this was not observed in the present study, which showed a percentage increase of $7 \%$. This might be explained by the difference in methodology, such that one used a unipollutant model and the other used adjustment by other pollutants. In another study, which used a generalized linear model, sulfur dioxide was found to be a statistically significant risk factor for death due to stroke in the fifth and sixth moving means. ${ }^{4}$ This result is more similar to what was found in the present study, thus showing the importance of exposure to sulfur dioxide on the fifth day after exposure when using both the moving mean and the lag methodology. 
In turn, ozone was not a statistically significant risk factor in the present study, and this coincides with research using a generalized linear model for hospital admissions. ${ }^{8}$ The $5 \%$ higher interquartile difference in the third lag found in this study was close to what was found by Hong et al. (2.9\% on the same day as the exposure), but without statistical significance. ${ }^{16}$

It is important to remember that the present study only addressed stroke events that resulted in death. Another point to note is that the database used is susceptible to human error. On the other hand, this database (Datasus), which contains secondary records, is greatly used in studies on air pollution and its health effects. Ecological studies like the present study may have limitations in terms of confounders and ecological bias; moreover, epidemiological studies do not identify causes.

There may be delays between symptoms and death, or misdiagnosis or error in codings used for deaths, since the diagnosis of this disease is clinical and there may not have been any autopsy or examination like tomography to provide confirmation. Moreover, we considered homogeneous concentrations of pollutants, rather than individual exposure. The present study did not include or analyze any interactions with risk factors inherent to human health that have already been established for stroke. It is important to emphasize that these results do not determine causality, but rather, they indicate a possible association between exposure to pollutants and deaths due to stroke.

The strength of this study lies in the fact that it demonstrates the effect of air pollutant exposure on human health, even at low concentrations. Another positive point to be highlighted is that studies in medium-sized cities in which air pollutant concentrations are measured can use this methodology to assess these effects and to establish public health policies.

\section{CONCLUSION}

This study showed that there was an association between exposure to major air pollutants and deaths due to stroke, and it serves as an important tool for public health management.

\section{REFERENCES}

1. Arbex MA, Saldiva PH, Pereira LA, Braga AL. Impact of outdoor biomass air pollution on hypertension hospital admissions. J Epidemiol Community Health. 2010;64(7):573-9.

2. Maheswaran R, Haining RP, Brindley $P$, et al. Outdoor air pollution, mortality, and hospital admissions from coronary heart disease in Sheffield, UK: a small-area level ecological study. Eur Heart J. 2005;26(23):2543-9.

3. Nascimento LF, Pereira LA, Braga AL, Módolo MC, Carvalho JA. Efeitos da poluição atmosférica na saúde infantil em São José dos Campos, SP. [Effects of air pollution on children's health in a city in Southeastern Brazil]. Rev Saude Publica. 2006;40(1):77-82.
4. Amancio CT, Nascimento LF. Association of sulfur dioxide exposure with circulatory system deaths in a medium-size city in Brazil. Braz J Med Biol Res. 2012;45(11):1080-5.

5. Vidale S, Bonanomi A, Guidotti M, Arnaboldi M, Sterzi R. Air pollution positively correlates with daily stroke admission and in hospital mortality: a study in the urban area of Como, Italy. Neurol Sci. 2010;31(2):179-82.

6. Kettunen J, Lanki T, Tiittanen P, et al. Associations of fine and ultrafine particulate air pollution with stroke mortality in an area of low air pollution levels. Stroke. 2007;38(3):918-22.

7. Tsai S, Goggins WB, Chiu HF, Yang CY. Evidence for an association between air pollution and daily stroke admissions in Kaohsiung, Taiwan. Stroke. 2003;34(11):2612-6.

8. Nascimento LF, Francisco JB, Patto MB, Antunes AM. Environmental pollutants and stroke-related hospital admissions. Cad Saude Publica. 2012;28(7):1319-24.

9. Lisabeth LD, Escobar JD, Dvonch JT, et al. Ambient air pollution and risk for ischemic stroke and transient ischemic attack. Ann Neurol. 2008;64(1):53-9.

10. Brasil. Ministério da Saúde. Portal da Saúde. Saúde lança consulta pública para o aprimoramento da assistência a pacientes com AVC. Available from: http://portal.saude.gov.br/portal/aplicacoes/ noticias/default.cfm?pg=dspDetalheNoticia\&id_area $=124 \& C O$ _ NOTICIA=11825. Accessed in 2013 (Oct 18).

11. Brasil. Ministério da Saúde. DATASUS. Informações de Saúde. Epidemiológicas e morbidade. Morbidade hospitalar do SUS - por local de residência - SP. Available from: http://tabnet.datasus.gov.br/ cgi/tabcgi.exe?sih/cnv/nrsp.def. Accessed in 2013 (Oct 18).

12. Cançado JE, Braga $A$, Pereira LA, et al. Repercussões clínicas da exposição à poluição atmosférica [Clinical repercussions of exposure to atmospheric pollution]. J Bras Pneumol. 2006;32 Suppl 2:S5-11.

13. Pope CA 3rd, Burnett RT, Thurston GD, et al. Cardiovascular mortality and long-term exposure to particulate air pollution: epidemiological evidence of general pathophysiological pathways of disease. Circulation. 2004;109(1):71-7.

14. Companhia Ambiental do Estado de São Paulo. Qualidade do ar. Available from: http://www.cetesb.sp.gov.br/ar/qualidade-do-ar/31publicacoes-e-relatorios. Accessed in 2013 (Nov 18).

15. Wellenius GA, Schwartz J, Mittleman MA. Air pollution and hospital admissions for ischemic and hemorrhagic stroke among Medicare beneficiaries. Stroke. 2005;36(12):2549-53.

16. Hong YC, Lee JT, Kim H, et al. Effects of air pollutants on acute stroke mortality. Environ Health Perspect. 2002;110(2):187-91.

17. Conceição GMS, Saldiva PHN, Singer JM. Modelos MLG e MAG para análise da associação entre poluição atmosférica e marcadores de morbi-mortalidade: uma introduçäo baseada em dados da cidade de São Paulo [GLM and GAM model for analyzing the association between atmospheric pollution and morbidity-mortality markers: an introduction based on data from the city of São Paulo. Rev Bras Epidemiol. 2001;4(3):206-19. 
18. Blasko I, Stampfer-Kountchev M, Robatscher P, et al. How chronic inflammation can affect the brain and support the development of Alzheimer's disease in old age: the role of microglia and astrocytes. Aging Cell. 2004; 3(4):169-76.

19. Calderón-Garcidueñas L, Solt AC, Henríquez-Roldán C, et al. Longterm air pollution exposure is associated with neuroinflammation, an altered innate immune response, disruption of the blood-brain barrier, ultrafine particulate deposition, and accumulation of amyloid beta-42 and alpha-synuclein in children and young adults. Toxicol Pathol. 2008:36(2):289-310.

20. Tamagawa E, van Eeden SF. Impaired lung function and risk for stroke: role of the systemic inflammation response? Chest. 2006;130(6):1631-3.

21. D'Mello C, Le T, Swain MG. Cerebral microglia recruit monocytes into the brain in response to tumor necrosis factoralpha signaling during peripheral organ inflammation. J Neurosci. 2009;29(7):2089-102.

Sources of funding: São Paulo Research Foundation (Fapesp), grant number 2012/09371-9

Conflict of interests: None

Date of first submission: June 12, 2013

Last received: November 7, 2013

Accepted: November 18, 2013

\section{Address for correspondence:}

Luiz Fernando Nascimento

Avenida Tiradentes, 500

Bom Conselho — Taubaté (SP) — Brasil

CEP 12030-180

Tel. (+55 12) 3625-4271

E-mail: luiz.nascimento@feg.unesp.br

E-mail: luiz.nascimento@unitau.com.br 